\title{
Introduction to Leadership, Popular Culture and Social Change Kristin M.S. Bezio
}

Civilization is made up of many components, including religion, politics, social structure and historical narrative. Michael Harvey, in an essay on "Leadership and the Human Condition," explains that "One way by which humans construct their reality is through storytelling ... Stories connect reason, emotion, intuition, and the subconscious ... A story offers an account of reality that seeks either to affirm or contest an existing terrain of meaning" (Harvey, 2006, p.43). Leadership studies recognizes the significance of such stories, but outside of the fields of literary analysis (which, in many institutions, includes analysis of cinema, television and other similar media), communication studies and art history, we very often overlook an important component of any civilization's storytelling zeitgeist - its popular culture.

In our modern lexicon, "culture" is given an intellectual valence, associated with "the arts" as elite or spiritual pursuits. "Culture," explains Lionel Trilling, "is not a flow, nor even a confluence; the form of its existence is struggle, or at least debate - it is nothing if not a dialectic" (Trilling, 2008, p.9). In essence, Trilling argues that we can come to understand the debates of any historical time and place through an examination of its culture. Culture is therefore, by this definition, a selective representation of the higher echelons or those who form and dictate social and political moresin other words, our leaders.

By contrast, "popular" is vulgar, widespread, something enjoyed or participated in by the proverbial unwashed masses. "Popular" as a modifier is applied to a variety of terms, and typically contains a derogatory or dismissive valence. The addition of "popular" to "culture" thus diminishes it, reduces it from the pinnacle of artistic creation to something shallow, "pure entertainment" such as that offered by pop stars, pop music or pop art. "Popular culture" is therefore commonly associated with the young, the uneducated, the mob. Popular culture includes music, television, movies, social media, Internet culture and video games. In any given year, 
we are able to list titles, celebrities and genres, the vast majority of which we likely dismiss as valueless or shallow.

However, to do so, to view popular culture as vulgar entertainment without deeper meaning or purpose, is to profoundly misapprehend the value and role of popular culture to civilization and to leadership. Put simply, through the practice of leadership, popular culture helps to both reinforce and question our understanding of who "we"-both as individuals and as members of a civilization - are and what we should strive to become or accomplish as citizens, leaders and followers. Furthermore, as Trilling suggests of culture more generally, popular culture engages on multiple levels with contextual social and political concerns, capturing and driving debates on core issues of religion, economics, security and domestic and international politics, as well as questions of personal and relational identity. In short, popular culture provides a distillation of the concerns facing a civilization at a particular sociohistorical moment. As such, a civilization's popular culture provides an image of its conflicts concealed within a package of "popularity" designed to neutralize its criticisms behind the mask of "entertainment."

For the sake of this project, it is vitally important to remember that the distinction between "culture" and "popular culture" is entirely fabricated. "Culture," as it appears in art and literature, is "popular culture" with an elitist veneer; for example, William Shakespeare, widely considered to be the epitome of Western high literary culture, was in his own day lambasted for his vulgarity and popularity. Furthermore, Shakespeare has reappeared in the popular cultures of every historical era from his own to the present day. This is not to say that every work of popular culture has equal depth or complexity to Shakespeare - but it is a caution against dismissing all popular culture as irrelevant or vapid. All cultural artifacts are or have been popular; they would not have power or meaning without some level of popularity.

This notion of popularity, of requiring an audience, brings us back to the relationship of popular culture to leadership studies. If a leader requires followers to be effective, a work of popular culture similarly requires an audience to disseminate meaning. Thus, fans of a particular work of popular culture are the most devoted of followers, but any consumer of pop culture becomes a follower in the act of reading, watching, viewing or playing.

This linkage between followership and consumption presents an interesting, and problematic, opportunity to consider leadership (and leaders) as a product, although that is not our project here. Rather, we use this link as a means of determining a work's influence; the higher the level of consumption, the more followers a work of popular culture reaches and the 
larger its potential sphere of influence. What this means is that the more popular a work is, the more potential influence - the more power-it has.

One of the most notorious examples of popular culture enacting leadership for social change concerns the publication of Harriet Beecher Stowe's Uncle Tom's Cabin (1852), a novel which galvanized the abolition movement in the United States. In 1852, Stowe's novel sold more than 300,000 copies in the United States (Hagood, 2012, p. 71), meaning that it was purchased by 1.5 percent of the non-slave population (approximately 3 percent of the literate population) (U.S. Department of Commerce, 1975). For comparison, a book published today would need to sell 4,738,761 copies in its first year in order to match the popularity of Uncle Tom's Cabin. For Southern plantation readers, Stowe's novel was lambasted as slander, and, Hagood notes, "Alabama burned shipments of it" and "Maryland jailed a free Negro preacher for having a copy" (2012, p. 72). However, in other parts of the country - and even some parts of the South - it was widely popular, "and a bookseller in Columbia, South Carolina 'complained that he could not keep up with demand for it"' (Hagood, 2012, p. 72).

In addition, Stowe's novel initiated a wave of 'response novels' and critical publications, including Mary Eastman's Aunt Phillis's Cabin (1852), Caroline Lee Hentz's The Planter's Northern Bride (1854) and Stowe's counterpoint, A Key to Uncle Tom's Cabin (1854), in addition to any number of more typical reviews in journals and newspapers (Hagood, 2012 , p. 73). The widespread publication of the novel-and its reception, as it was both beloved and hated by its readership, depending on their demographic origins - offers a quantitative measure of its influence, while readers' responses suggest the equal significance of a qualitative analysis.

As Hagood observes, Uncle Tom's Cabin "opened the floodgates for open conversations about the pros and cons of slavery-floodgates that decades of American male politicians had struggled to keep shut" (2012, p. 71). According to the diary of one Susan Bradford, a woman writing in 1861 Florida, Stowe's novel was responsible in no small part for the antislavery politics that produced the American Civil War: "If Mrs. Harriet Beecher Stowe had died before she wrote 'Uncle Tom's Cabin," wrote Miss Bradford, the daughter of a plantation owner who also owned more than 300 slaves, "this would never have happened ... she has kindled a fire which all the waters of the earth cannot extinguish" (Hagood, 2012, p. 71). We cannot, of course, directly attribute, as does Miss Bradford, the Civil War to the publication of Uncle Tom's Cabin, but we can certainly recognize the cultural influence of the novel in galvanizing widespread discussions of abolition around the country.

The example of Stowe's Uncle Tom's Cabin demonstrates that our impulse to dismiss popular culture as "just" entertainment, particularly the 
more popular it is, reveals a profound disconnect between what influences us the most and what we identify as influential. Interestingly, this disconnect is part of what enables popular culture as leadership to be so powerful, particularly as a vehicle for ideological subversion. Although much popular culture reinforces the status quo of its time, even to the degree of becoming propagandistic, popular culture has also been responsible - as with Stowe's Uncle Tom's Cabin - for profound cultural and ideological rebellion throughout history.

At its core, the study of popular culture is the study of social history through a society's stories - an examination of the ideological dialectic between those with and those without power concealed within fictional and fictionalized representations and narratives of identity. When we analyze and interrogate popular culture with a critical eye, then, we focus on both the positive and problematic aspects of our socio-political milieu. Such an examination is particularly important in leadership studies in dual terms. First, and most obviously, it tells us what we expect of - and fear from-our leaders. Second and, we argue, more importantly, the study of popular culture opens up a critical space in which to question the oppressive and exclusive structures in place in our society in the interest of inclusivity and social justice. It is the second of these which we find most valuable to - and, unfortunately, most neglected in —leadership studies.

\section{THIS VOLUME}

It is our intention to demonstrate that popular culture, rather than being peripheral to civilization, in fact occupies a focal point at its center, both reflecting and shaping the ideological traces which run through, support and potentially even undermine dominant paradigms. The chapters in this volume examine a collection of examples of popular culture-both in the United States and around the globe - as such galvanizers of social change, both within their specific contexts and in a larger, more universal sense. With this mingled parochial and global sense of culture in mind, we have divided the volume into generic sections, each of which addresses a broad category of popular culture.

The first section - "Written Leadership"- is the most traditional, examining works of literature which directly engage with social concerns across a global context. As a genre, literature is among the most commonly studied forms of popular culture, typically placed in an historical context which distinguishes between "literature" and "pulp," "popular" or "genre" fiction. Our examination of the power of popular written works transects these "sub-genres," presenting examples from around the globe which 
engage with traditional and modern works of literature openly advocating for social transformation.

We begin with an example of "old school" popular culture - a play from the sixteenth century by playwright Christopher Marlowe, a contemporary of William Shakespeare. According to early modern scholar Kristin M.S. Bezio, in Marlowe's play The Massacre at Paris, the playwright uses contemporaneous events in Paris to comment on the need for change in English governmental policies surrounding religious intolerance. From the sixteenth century, we jump forward and across oceans to the writings of Malay-Muslim author Abdullah Munsyi, whose work in the nineteenth century, according to Kavitha Ganesan, created a framework for modern Malay writers to explore their cross- and inter-cultural identities and advocate for increased tolerance and diversity in post-colonial Malaysia.

The remaining two chapters in the "Written" section are more modern, looking at novels from the twentieth and twenty-first centuries. Mark A. Menaldo's examination of Mario Vargas Llosa's The Feast of the Goat situates Llosa's historical fiction about Dominican dictator Rafael Trujillo as an expression of the national trauma that still resonates in the Dominican Republic following his assassination. Kimberly Yost's chapter on the Harry Potter series by J.K. Rowling identifies Rowling's young adult series as a modern epic narrative drawn from Classical and fairy tale traditions that encourages its readers to engage in the leadership practice of resistance.

In the second section, we move from the written word to the sung, with chapters that contextualize and analyze song lyrics and music which reflect and challenge dominant ideological paradigms. The "Aural Leadership" section draws upon a tradition of music of resistance and protest, featuring chapters which examine song-as-protest in both North and South America.

Susan J. Erenrich's chapter on women troubadours in the U.S. Civil Rights Movement narrates the trajectory of women singers-songwriters on the path toward Civil Rights during the Southern Freedom struggle in 1964 in the Deep South. She analyzes the work being done by these women in and through music, situating their voices at the crux of the Southern Freedom movement. Similarly, Patricia D. Catoira and Virginia $\mathrm{K}$. Bratton examine the countercultural music of Mexican narcoculture folk ballads which valorize and celebrate the controversial figure of El Chapo. The section concludes with a chapter from Shawna Guenther, who examines the charismatic and fluid identity leadership of David Bowie, which encourages his audience to not only tolerate but also embrace Otherness.

In our third section, we add a visual component to the aural/oral, interrogating cinematic, graphic and video game works from the twentieth 
and twenty-first centuries. This section, "Visual Leadership," focuses on works which demonstrate the power of visual images over our collective social imaginations, foregrounding the social and cultural impacts of visual media.

Nicholas O. Warner's critical examination of leader-follower relationships in military films - specifically, Glory and Twelve O'Clock Highforegrounds the importance of "followers to the leadership process and to the social or cultural transformations that result from that process," as he writes in Chapter 8. Kimberly Yost focuses in her chapter on the science fiction films of Neill Blomkamp, a South African director whose work uses literal physical transformation to depict the process of personal change, which produces (occasionally unwilling) leadership among those impacted by the transformative process.

Kristin M.S. Bezio's chapter on video games explores the potential impact of interactive play combined with the visual and aural cues of games, suggesting that interactivity can be used to promote considerate leadership, diversity, creativity and cooperation as tools of social change. Similarly, Kimberly Klimek examines the ways in which video games, graphic novels and comics, and the popular culture practice of cosplay ("costume-roleplay") can be used in the classroom to help students of history - and leadership in history - form a more affective connection to the lessons of history and historical leadership.

Our final section, "Digital Leadership," presents analyses of digital cultures, an area of yet-undeveloped research and inquiry, examining social media and digital art and art communities. In this section, the chapters foreground digital practices, platforms and communities, all oriented at providing space in which social change can be created and fostered.

Eileen Mary Holowka's chapter on the "Sad Girls" of Instagram-a social media image-sharing platform - examines the formation of identity and community through the use of particular images and ideologies in social media spaces. Similarly, Laura DelPrato's chapter on a form of long-exposure photography known as light painting mixes analysis of images and communities to discuss the ways in which online community groups create digital space in which to share art expressly for the purpose of encouraging global cooperation and social transformation. Finally, the section concludes with Holly Connell Schaaf's examination of the world of Wikipedia and its use as a transformative tool in the classroom to teach both students and professors how to use digital communities to engage in collaborative leadership as a means of creating a more inclusive and egalitarian society.

Taken all together, this volume can offer only the briefest of snapshots of each of these generic categories and their potential to reflect, shape 
and even revolutionize social and political ideologies. Each category is, of course, so much broader and more diverse than we can possibly hope to contain in a single volume, and it is our hope that future scholars of leadership and popular culture will seek to fill the gaps. We believe, as this volume should make evident, that works and creators of popular culture are engaging directly with the most pressing questions and problems of their context and that their creators use these works to effect change for both themselves and the wider world around them.

As popular culture is ubiquitous, so, too, is its capacity for critical engagement with the ideas and practices that shape how we think about ourselves, our societies and - of course - our leaders and leadership practices. Put simply, popular culture helps to both reinforce and question our understanding of who "we" — both as individuals and as members of a civilization - are and what we should strive to become or accomplish.

\section{REFERENCES}

Hagood, T.C., 2012, “'Oh, what a slanderous book': Reading Uncle Tom's Cabin in the Antebellum South", Southern Quarterly, 49, 71-93.

Harvey, M., 2006, "Leadership and the human condition", in G.R. Goethals and G.L.J. Sorenson (eds), The Quest for a General Theory of Leadership, New Horizons in Leadership Studies series, Cheltenham, UK and Northampton, MA, USA: Edward Elgar, pp. 39-45.

Trilling, L., 2008, The Liberal Imagination: Essays on Literature and Society, New York, NY: The New York Review of Books.

U.S. Department of Commerce, 1975, Historical Statistics of the United States: Colonial Times to 1970, Bureau of the Census, https://www.census.gov/history/ pdf/histstats-colonial-1970.pdf, accessed 15 September 2017. 
Kristin M.S. Bezio - 9781785368974 Downloaded from PubFactory at 04/26/2023 $02: 21: 13 \mathrm{AM}$ via free access 